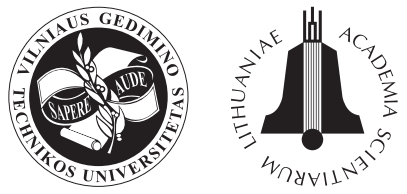

TRANSPORT

2010

25(4): 387-393

\title{
A NEW APPROACH TO ESTIMATING THE OCCUPATION TIME OF THE RAILWAY INFRASTRUCTURE
}

\author{
Jozef Gašparík ${ }^{1}$, Vladislav Zitrický \\ 1, ${ }^{2}$ Faculty of Operation and Economics of Transport and Communication, \\ University of Žilina, Univerzitna 1, 01026 Zilina, Slovak Republic \\ E-mails: ${ }^{1}$ Jozef.Gasparik@fpedas.uniza.sk; ${ }^{2}$ Vladislav.Zitricky@fpedas.uniza.sk
}

Received 17 February 2010; accepted 15 November 2010

\begin{abstract}
The paper describes UIC methodology and a technique used by Slovakian infrastructure managers for estimating railway capacity and proposes a new approach to evaluating the capacity consumption of a track line (occupation time) based on the graphic approach. The new methodology concerns for the assessment of infrastructure occupation time and is a conceptual framework developed by the authors for an easier evaluation of occupation time in the train traffic diagram.
\end{abstract}

Keywords: ŽSR methodology, UIC methodology, train traffic diagram, railway capacity, infrastructure occupation.

\section{Introduction}

The problem of estimating time table construction and railway infrastructure capacity is very specific in railway transportation. The definition of railway network capacity is one of the key issues of capacity management. Capacity expresses the business of an infrastructure manager offered by allocating train paths to railway undertakings. The most frequently used definition includes that practical capacity is the quantum of the allocated train paths on the track section until it is possible to manage traffic at a satisfactory qualitative level (Hertel 1992; Gašparík and Pečený 2009).

There are a variety of methodologies for capacity estimation used by infrastructure managers across Europe. Based on the reformation of the European railway companies with the separation of infrastructure and exploitation, the working group of the capacity management of the International Union of Railways (UIC) drew up a new version of the UIC Code 406 'Capacity' (UIC... 2004). The aim of this leaflet is to enable infrastructure managers to carry out capacity calculations following common definitions, criteria and methodologies from an international standpoint - for lines or corridors based on different criteria such as traffic quality, timetable quality or effective and economical utilization of the infrastructure.

This paper describes and compares two methodologies one of which is used by the infrastructure manager in Slovakia (ŽSR - Železnice Slovenskej Republiky) and the second is applied in the UIC methodology.

Consequently, a new approach to the estimation of capacity consumption (occupation time) based on the graphic UIC approach was developed by the authors. The new methodology is a conceptual framework for an easier evaluation of occupation time in the train traffic diagram.

\section{Methodology Used by the Infrastructure Manager in Slovakia (ŽSR)}

Railway infrastructure capacity on the ŽSR network is expressed by the practical capacity value which means the quantity of train traffic sustained and regularly manageable on the given technical and traffic track equipment in most of cases taking a 24 hour time period. The capacity of the railway infrastructure embraces track capacity, railway station capacity and capacity for supplying electrical equipment. The methodology of capacity estimation is introduced in the internal ŽSR Regulation (D 24... 1965).

A track section is the most important operational equipment for the estimated capacity where graphical or analytical ways of capacity estimation are combined (Gašparík and Pokorný 2007).

The graphical approach is based on the construction of the graphical working plan of operational equipment or an element (time table). All requested actions are arranged considering railway traffic, thus this ele- 
ment can work properly and continuously. If there is some space for more trains, the following train paths are added. There is a need to respect all relevant time intervals. The drowned trains are summed up in the boundary stationary section which indicates the capacity of the track line (the number of train paths per time period). Also, the first step to find a boundary inter-stationary section where occupation time for planning train sequences is defined.

This fact is also relevant in the case of an analytical approach. The total occupation time of all estimated trains as a conjunction of the number of corresponding trains and particular occupation time periods is calculated. Next, an average infrastructure occupation per one train path $t_{o b s}$ as well as buffer time per train path $t_{\text {medz }}^{\text {poz }}$ is calculated and an effective (practical) capacity of the track line section is estimated:

$$
\left.n=\frac{T-\left(T_{v y l}+T_{\text {stal }}\right)}{t_{o b s}+t_{\text {medz }}^{\text {poz }}} \text { [train paths per time window }\right] \text {, }
$$

where: $n$ - practical capacity [train paths per day]; $T$ time window $[\mathrm{min}] ; T_{v y l}$ - supplement for maintenance [min]; $T_{\text {stal }}$ - fixed occupation [min]; $t_{o b s}$ - average occupation per one train path $[\mathrm{min}] ; t_{\text {medz }}^{\text {poz }}$ - buffer time per one train path according to the ŽSR Regulation D 24 (1965) [ $\mathrm{min}]$.

On the double track line, capacity is calculated separately for each track (direction).

\section{UIC Methodology}

The UIC methodology is an easy and effective way of calculating capacity consumption; however, it is possible to expound the UIC Code 406 method in different ways which can lead to different capacity consumptions. The main problem is to study relations between capacity consumption, time supplements and punctuality. The estimation of capacity consumption is executed with support by common simulation tools. The methodology does not exactly work out how to find out capacity consumption.

According to the UIC Code 406, the capacity of the railway infrastructure is the total number of possible train paths in a defined time window considering the actual path mix or known developments respectively and personal assumptions of infrastructure managers in nodes, individual lines or a part of the network taking into account market-oriented quality (UIC... 2004).

This methodology is based on the graphical compression of train paths within defined compression sections to find out consumption time on the section. Such compression considers minimum headways that depend on a signalling system and train characteristics (see Figs 1 and 2).

Consumption time represents the time when the regarded section is occupied by train paths. A high degree of occupation indicates a possible capacity bottleneck. Lower consumption times may indicate a lack of traffic and income for the infrastructure manager. However, the

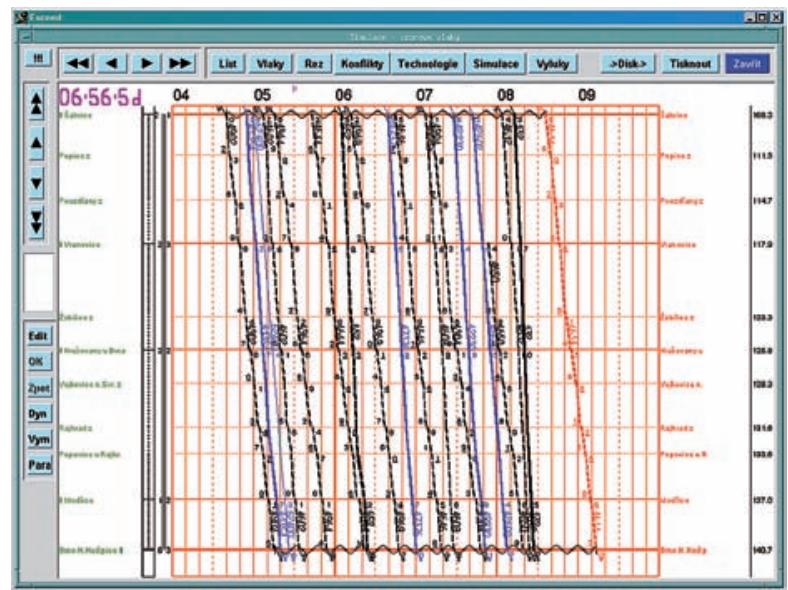

Fig. 1. A Train traffic diagram - trains on the double track line (Sadloň and Bachratý 2004)

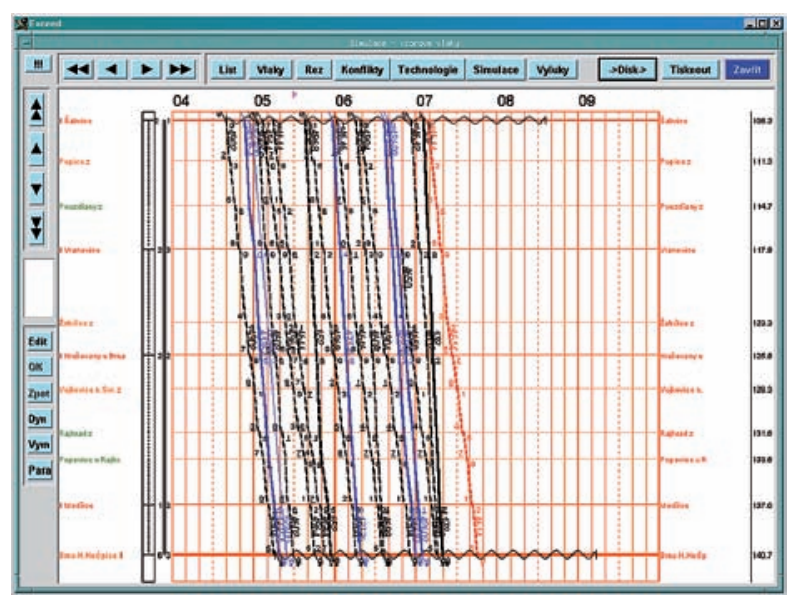

Fig. 2. A train traffic diagram - trains after compression according to the UIC Code 406 (Sadloň and Bachratý 2004)

evaluation of capacity using the UIC 406 methodology supports infrastructure managers to create the network in the most efficient and suitable way.

The application of UIC 406 starts with defining all network sections having wide compression. The representation of trains per network link via interface allows the identification of the suitable sections.

A wide application of the network employing the UIC-Method allows a standardized evaluation of bottlenecks and usable spare capacity. Actually, the method is applied for investigating future scenarios regarding different traffic forecasts and infrastructure variants. Additional paths have to be saleable, i. e. have a possibility of adding them into a timetable with a minimum of conflicts on long route sections.

The formula for determining capacity consumption according to the UIC Code 406 is:

$$
k=A+B+C+D \quad[\min ]
$$

where: $k$ - total consumption time [min]; $A$ - infrastructure occupation [min]; $B$ - buffer time [min]; $C$ - supplement for single-track lines $[\mathrm{min}] ; D$ - supplements for maintenance [min]. 
Capacity consumption is defined:

$$
K=\frac{k}{U} \cdot 100 \quad[\%],
$$

where: $K$ - capacity consumption [\%]; $U$ - chosen time window [min].

Capacity consumption is characterized by the value of infrastructure occupation (\% of a time-window). The UIC Code 406 gives typical values corresponding to the type of a track (see Table 1). If infrastructure occupation [\%] is higher or equal to this certain typical value, the analyzed line section should be called congested infrastructure and no more additional train paths might be added to the timetable. If occupation is lower than a certain typical value, capacity analysis must be further developed concerning the incorporation of the additional train paths of the type corresponding to the particular area into the timetable. If such incorporation is impossible, leftover capacity is lost capacity which cannot be used any longer. If this incorporation is possible, a certain part of leftover capacity will become usable capacity. In this case, further analysis must be carried out starting from the compression of the timetabled train paths including additional train paths. This procedure can be repeated until either infrastructure occupation reaches the congestion level.

On the condition that buffer times are sufficient for timetable stability, capacity consumption can theoretically reach $100 \%$ of the time-window considered. If it is greater, the infrastructure is congested.

This methodology is sufficient for estimating time occupation on double tracked lines (Gašparík and Zitrický 2008).

\section{Proposal for a New Methodology Estimating Occupation Time}

The new approach to researching occupation time (consumption time) is proposed in accordance with the UIC Code 406. This methodology estimated capacity consumption differently. There is no necessity to exercise the consumption procedure by simulation progress. The new approach is also based on the graphical methodology. The constructed train diagram defines occupation surface (the so called occupation squares) done by the conjunction of distance and time in the train traffic diagram (Gašparík and Zitrický 2008). The share of all occupation surfaces on the total surface of the graphic train diagram (time window, see Fig. 3) presents the occupation rate (capacity consumption). The proposed formula of the occupation rate is:

$$
S_{V}=\frac{\sum_{i=1}^{n} S_{o b s i}+\sum_{j=1}^{m} S_{P V j}}{S_{T}} .100 \quad[\%],
$$

where: $\sum S_{o b s i}$ - a sum of occupation squares in the block sections; $\sum S_{p V j}-$ a sum of occupation squares by track time intervals and station time intervals (in case of one-way traffic - train sequence intervals and in case of one-track line - crossing intervals and stepwise arrival intervals); $S_{T}$ - a square of time window (peak hour or all day); $i-1 \ldots n$, where $n$ is the number of occupation squares in the block section; $j-1 \ldots m$, where $m$ is the number of occupation squares of operation time intervals (in the station and in block sections).

The value of the occupation rate expresses infrastructure capacity occupation considering necessary occupation times in per cent.

Occupation square in block section $S_{o b s i}$ is defined by the conjunction of the block section and travelling time in this section (see Fig. 4).

The occupation squares of track time intervals and station time intervals $S_{P V}$ are designed in several variants according to different track safety devices and a train control system. The squares were defined in compliance with the Regulation D 23 of ŽSR (D 23... 1968) view to the graphic interpretation of the following train intervals. There is a similar definition as is common in Western Europe - an average buffer time between two trains should not be a lot less than the average minimum

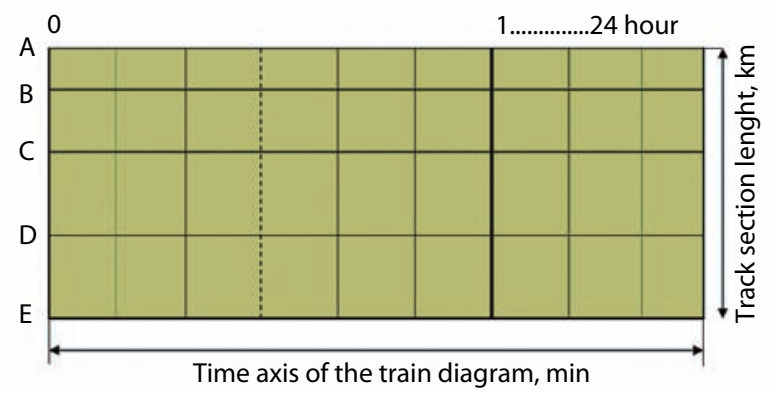

Fig. 3. A square of the time window (all day) $S_{T}$ in the analyzed track section

Table 1. The recommended limits of consume capacity in the UIC Code 406 (UIC... 2004)

\begin{tabular}{lccc}
\hline \multicolumn{1}{c}{ Type of line } & Peak hour & Daily period & Comment \\
\hline $\begin{array}{l}\text { Dedicated suburban } \\
\text { passenger traffic }\end{array}$ & $85 \%$ & $70 \%$ & $\begin{array}{l}\text { The possibility of cancelling some services } \\
\text { allows for high levels of capacity utilisation }\end{array}$ \\
\hline $\begin{array}{l}\text { Dedicated } \\
\text { high-speed lines }\end{array}$ & $75 \%$ & $60 \%$ & \\
\hline Mixed-traffic lines & $75 \%$ & $60 \%$ & $\begin{array}{l}\text { Can be higher when the number of trains is } \\
\text { low (smaller than 5 per hour) with strong } \\
\text { heterogeneity }\end{array}$ \\
\hline
\end{tabular}




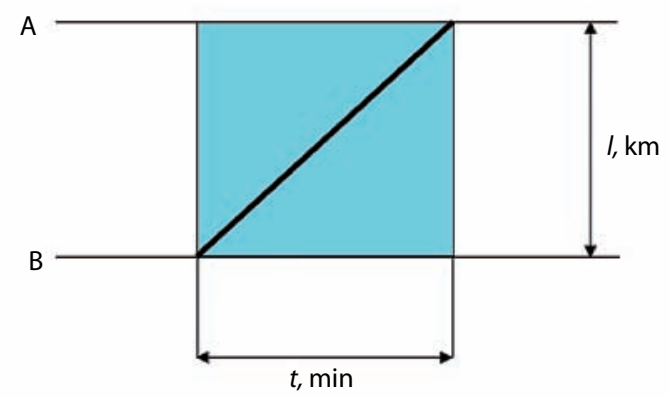

Fig. 4. Occupation square $S_{\text {obsi }}$ in the block section

line headway (Hansen and Pachl 2008). In principle, occupation square is done by the conjunction of the operation time interval (in a station or block section) and the distance between stations or block signals.

Occupation squares representing track intervals are estimated in:

- the case when an inter-stationary section is simultaneously one block section (not divided into more block sections) - see Fig. 5;

- the case when an inter-stationary section is divided into sections of a few blocks using block signals (the signals are operated by the staff) see Fig. 6;

- the case when an inter-stationary section is divided into block sections using block signals (with automatic control by train running). The occupation squares for different situations resulting regarding train sequence are defined:

- both of them have equal running time (accrue from the axiom that the following train runs in a distance of three block sections). If the length of block sections are $l_{1}, l_{2}, l_{3} \ldots l_{n}$ and the running times of the train in block sections are $t_{1}, t_{2}, t_{3} \ldots t_{n}$ so the formula for the occupation square is (see Fig. 7):

$$
S_{P V}=2 \cdot\left(l_{1} \cdot t_{1}+l_{2} \cdot t_{2}+l_{3} \cdot t_{3}+\ldots+l_{n} \cdot t_{n}\right)
$$

- the first train is faster and the second is slower (accrue from the axiom that the following train runs in a distance of two block sections). In this case, the square surface of the time interval represented by the sum of squares is (see Fig. 8):

$$
S_{P V}=l_{1} \cdot t_{1}+l_{2} \cdot t_{2}+l_{3} \cdot t_{3}+\ldots+l_{n} \cdot t_{n}
$$

- the first train slower than the second one (the first train must entry the next station, the second may run in a distance of three block sections). The square surface of occupation time is represented by the sum of squares (see Fig. 9):

$$
S_{---}=\sum_{2}^{n}\left(l_{-1}+l_{-2}\right) \cdot t+l \cdot t
$$

The detailed estimation of occupation squares is evident from the corresponding figures.

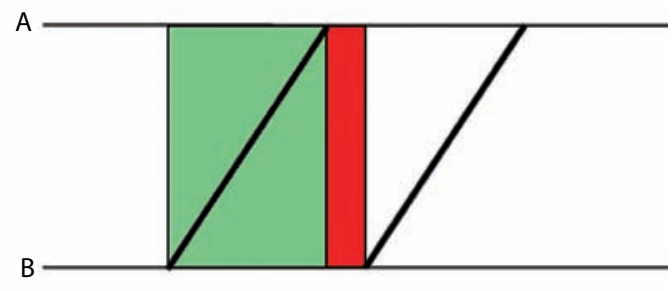

Fig. 5. The occupation square of track time intervals $S_{P V}$ - a simple inter-stationary section

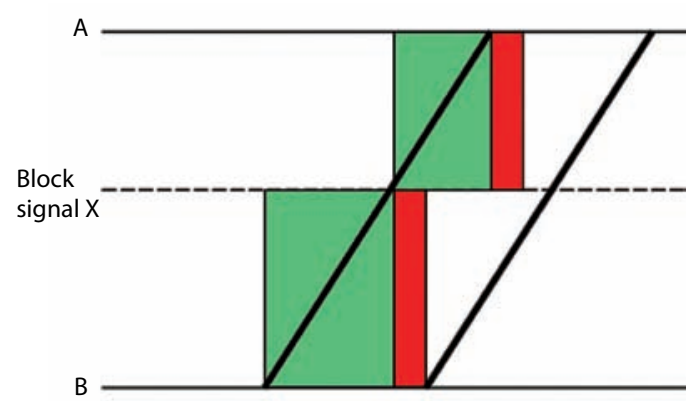

Fig. 6. The occupation square of track time intervals $S_{P V}-$ an inter-stationary section divided into block sections

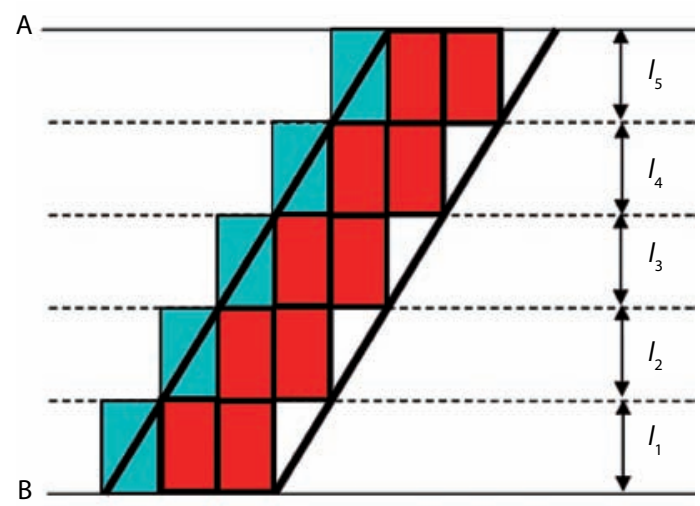

Fig. 7. The occupation square of track time intervals $S_{P V}-$ an inter-stationary section is divided into block sections (automatic signals) - equally running trains

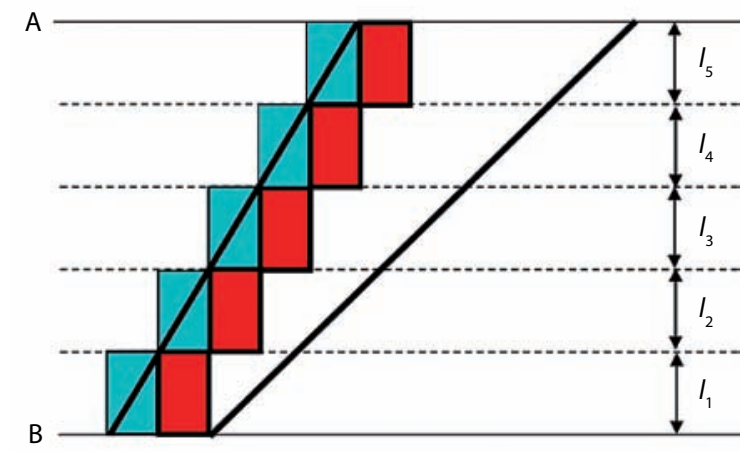

Fig. 8. The occupation square of track time intervals $S_{P V}$ - an inter-stationary section is divided into block sections (automatic signals) - the first train faster, the second train is slower 


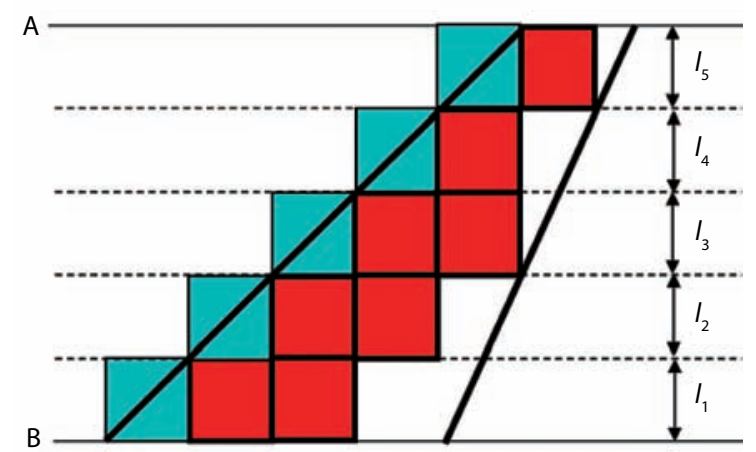

Fig. 9. The occupation square of track time intervals $S_{P V}$ - an inter-stationary section is divided into block sections (automatic signals) - the first train slower than the second one

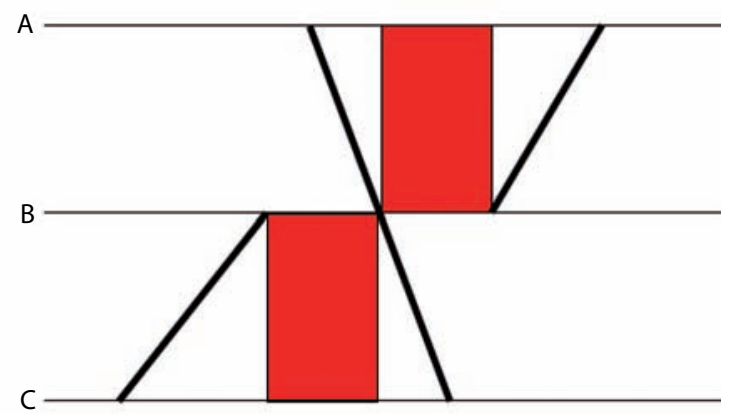

Fig. 10. The occupation squares of station time intervals (one track line - bi-directional traffic)

The formula of the occupation rate is the same for estimating one-track lines and double-track lines (4). In case of the train crossing the station, the sum of occupation squares is estimated differently. It is necessary to set station time intervals (crossing intervals, stepwise arrival intervals, stepwise departure intervals and stepwise arrival-departure intervals) according to the ŽSR methodology (D 23... 1968). Occupation square is done as a junction of this station interval and the distance of the relevant block section (see Fig. 10). If the trains follow each other, it is necessary to estimate occupation time as in the case of the double track line.

The inspection of occupation time according to the new methodology consists of these steps (Gašparík 2009):

1. the estimation of the infrastructure occupation rate - formula (4);

2. if the infrastructure occupation rate is higher or equal to a certain typical value (see Table 1 ), the infrastructure is congested, whereas if the rate is lower, then a certain typical value goes to step 3;

3. capacity analysis should be developed further adding additional train paths typical for the examinant time window and track line until the typical value is reached (see Table 1);

4. estimating infrastructure capacity as the percentual infrastructure occupation rate (formula 4).
This proposed methodology of estimating infrastructure capacity is usable providing common timetabling software tools with graphical support. The incorporation of occupation square imaging to the common software (see Muthmann 2004; Gröger 2002; Šotek et al. 2008; Šotek and Bachratý 2009) is not that difficult from the point of view of software creation. Software will fulfil the task of an easy calculation of squares in the train graphic diagram (time-table).

\section{Case Study}

The authors of the methodology made a case study for the verification of the proposed methodology in terms of real time table conditions (Gašparík et al. 2008). Capacity estimation was carried out employing software ZONA-CP-VT that uses ŽSR for time table construction. This software is eligible for applying the new methodology and will be required only for insignificant software modification to ensure drawing occupation squares in the train traffic diagram.

For the case study, track section Zbehy - Leopoldov on ŽSR railway network was chosen. The line has onetrack and mixed traffic for both passenger and freight trains. The obtained results are introduced.

47 regular train paths are presented in the diagram. The researched time period embraces the whole day (time window period is $1440 \mathrm{~min}$ ).

According to the proposed methodology, the results are presented in Table 2. Step 1 evaluates capacity consumption in the outgoing state (see the fragment of the train diagram in Fig. 11). The occupation rate is $33.3 \%$. Capacity consumption does not reach the typical value of $60 \%$ under conditions of mixed traffic (see Table 1).

Following step 3, the added train paths were inserted in the train diagram. The additional train paths are typical for the examinant section; in this case, regional passenger trains and running freight trains were added (Fig. 12).

These paths must be inserted into the whole inspected track section until the occupation rate reaches the typical value of $60 \%$. The result in this case is 32 added train paths in the 24 hour time window. Capacity consumption is $58.43 \%$ and the capacity of the track section is 79 trains per day.

This result was compared with the current analytical methodology of ŽSR according to the Regulation D 24. The result of track capacities for the ŽSR network is listed in the internal document - the list of ascertained capacities (the so called booklet of capacities). Track section Zbehy - Leopoldov contains the capacity of 74 trains per day.

The estimation of time occupation according to the UIC methodology was not done due to the fact that this methodology gives no satisfactory result for one track lines, and therefore the problem of executing the graphical compression of the opposite running train paths occurs. In this regard, a comparison should not be purposeful. 


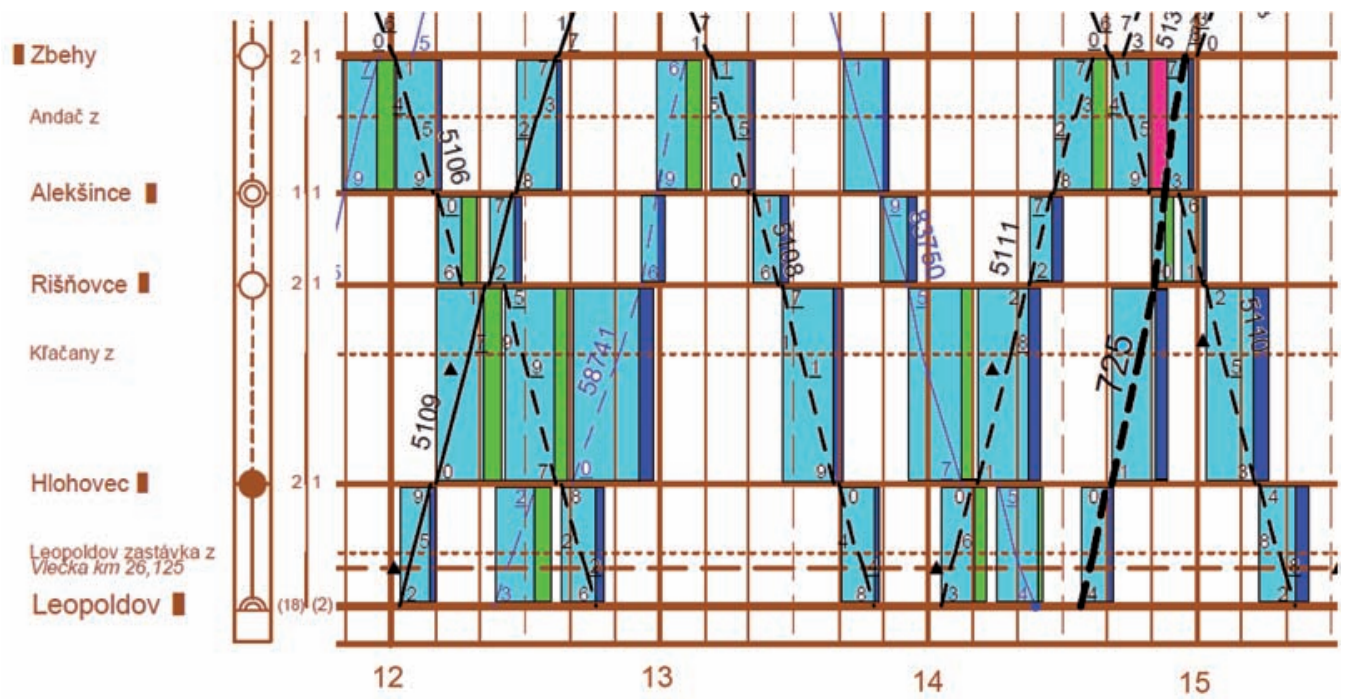

Fig. 11. Occupation squares in the fragment of the train traffic diagram with no added train paths (Gašparík et al. 2008)

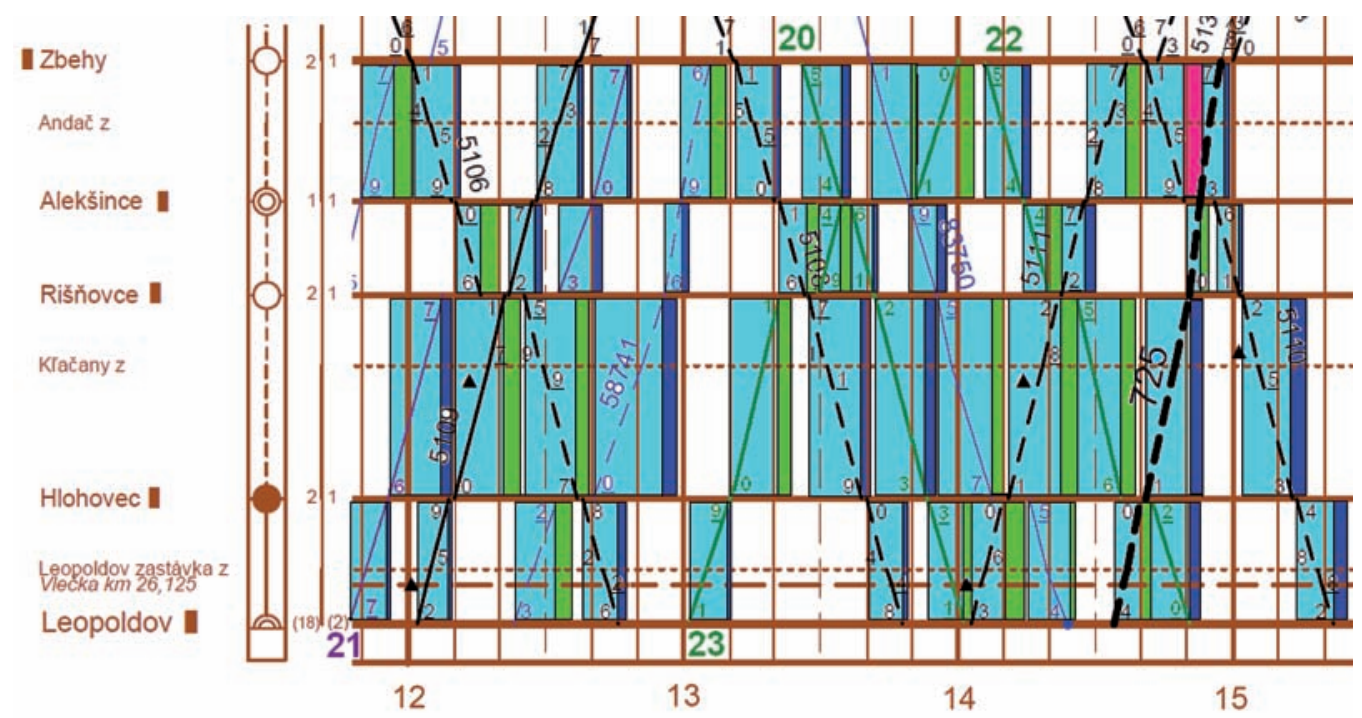

Fig. 12. Occupation squares in the fragment of the train traffic diagram with added train paths (Gašparík et al. 2008)

Table 2. The obtained results of the case study

\begin{tabular}{|l|c|c|}
\hline \multicolumn{1}{|c|}{ Indicator } & $\begin{array}{c}\text { Outgoing } \\
\text { number of } \\
\text { train paths }\end{array}$ & $\begin{array}{c}\text { Final } \\
\text { number of } \\
\text { train path }\end{array}$ \\
\hline $\begin{array}{l}\text { The number of regular train } \\
\text { paths in the train diagram }\end{array}$ & 47 & 47 \\
\hline The number of added train paths & 0 & 32 \\
\hline The total number of trains & 47 & 79 \\
\hline $\begin{array}{l}\text { The sum of occupation squares } \\
\sum_{i=1}^{n} S_{\text {obsi }}+\sum_{j=1}^{m} S_{P V j}(\text { min } / \mathrm{km})\end{array}$ & 11508.75 & 20194.05 \\
\hline $\begin{array}{l}\text { A square of day time window } S_{T} \\
\text { (min / km) }\end{array}$ & 34560 & 34560 \\
\hline Capacity consumption $(\%)$ & 33.3 & 58.43 \\
\hline
\end{tabular}

\section{Conclusions}

The burning problem of capacity estimation is connection with the liberalization of the infrastructure access.

A huge variety of methodologies for capacity estimation are used across Europe. Thus, the UIC methodology is not obligatory for infrastructure managers as in this case, different treatments are often used. An example of capacity estimation is introduced in (Wahlborg 2004).

The imperfections of the UIC methodology for consumption estimation are as follows:

- not exactly defined track section for capacity investigation;

- vagueness in defining occupation time after compression as there is disambiguation whether occupation time is regarded to the first or the last station on the track section. It can be also different if there are unparallel train paths; 
- not exactly defined capacity utilization on singletrack lines. The formula for railway infrastructure capacity consumption suggests equation term ' $\mathrm{C}$ ' which is the supplement to single-track lines; however, the UIC methodology provides nothing for solving the question and does not determine exactly capacity on single-track lines.

These disadvantages should be removed using an appropriate definition of simulation run. Cardinal improvements in the UIC methodology is a definition of occupation time by train paths in the time window calculated applying common simulation software. An important point is the estimation of unused (free) capacity as a compulsory indicator published by the infrastructure manager. The pivotal moment of capacity estimation is used to define the required quality of train traffic in the constructed time table. The presented new methodology of occupation time estimation based on the graphic approach makes the UIC methodology more usable and enables to obtain more exact results from infrastructure capacity examination. Common software tools for timetabling and capacity inspection need to be upgraded by adding the function analysing occupation squares.

The proposed methodology does not substitute simulation techniques giving a better result of capacity as these procedures consider the exact train mix and delays.

The new methodology introduced by the authors of this paper represents an efficient way of how to estimate occupation time in the train traffic diagram. The authors also propose this original methodology to be widely discussed by more experts in the field. It is easy to adapt to conditions for representing another train traffic diagram used in Western Europe as well as different software (Germany, Austria etc.). The authors adopted this approach considering conditions of Slovak railways. The methodology estimating railway capacity should be integrated into the UIC Code 406 and constitute the unified methodology for all infrastructure managers.

\section{References}

D 23 Služobný predpis pre stanovenie prevádzkových intervalov a následných medzičasov [Internal regulation for the time intervals and train sequence intervals estimation]. 1968. ŽSR. Praha: Nadas. 187 p.

D 24 Predpisy pre zistovanie priepustnosti železničných tratí [Internal regulation for estimation of railway routes capacity]. 1965. ŽSR. Praha: Nadas. 123 p.

Gašparík, J. 2009. Manažment kapacity železničnej infraštruktúry $v$ liberalizovanom trhovom prostredí [Management of railway infrastructure capacity in the liberalized market surroundings. Habilitation thesis, Transport Science]. Žilina: University of Žilina. 114 p.

Gašparík, J.; Pečený, Z. 2009. Grafikon vlakovej dopravy a priepustnost sietí: odborná publikácia [Railway Time Table and Capacity of the Networks. Monograph]. Žilina: University of Žilina. $258 \mathrm{p}$.

Gašparík, J.; Pokorný, J. 2007. The methodics of the calculation the railway infrastructure capacity, in Proceedings of the 5th Conference of European Students of Traffic and Transportation Science 'Transportation as a Mean of Globalisation', 155-160.
Gašparík, J.; Zitrický, V. 2008. Estimation of the occupation time in the railway traffic, in Proceedings of the 6th Conference of European Students of Traffic and Transportation 'Transport modal split as economic indicator', 34-41.

Gašparík, J., et al. 2008. Transport modal split model with the aspect of infrastructure capacity. Grant VEGA No. 1/0432/08, partial research report, Žilina: University of Žilina. 47 p.

Gröger, T. A. 2002. Simulation der Fahrplanerstellung auf der Basis eienes hierarchischen Trassenmanagements und Nachweis der Stabilität der Betriebsabwicklung. Aachen: Rheinisch-Westfalische Technische Hochschule. 181 p.

Hertel, G. 1992. Die Maximale Verkehrsleistung und die minimale Fahrplanempfindlichkeit auf Eisenbahnstrecken, Eisenbahntechnische Rundschau 10(1992): 665-671.

Hansen, I. A.; Pachl, J. 2008. Railway Timetable \& Traffic. Hamburg: Eurailpress. 228 p.

Muthmann, T. 2004. Rechnerische Bestimmung der optimalen Streckenauslastung mit Hilfe der Streckendurchsatzleistung. Darmstadt: Technische Universität. 179 p.

Sadloň, L.; Bachratý, H. 2004. Príspevok k testovaniu robustnosti časového plánu [The contribution to the testing of the robustness of the time plan], in Proceedings of the $\check{Z} e l$ 2004, 96-100.

Šotek, K., et al. 2008. Tvorba jízdního řádu na železnici s využitím výpočetní techniky: monografia [Timetabling on the railways with the usage of the IT. Monograph]. Pardubice: University of Pardubice. 129 p.

Šotek, K.; Bachratý, H. 2009. Koncepce směrující k inovaci tvorby jízdního řádu v železniční dopravě [The conception tending to the innovation of the time table arrangement], in Proceedings of the Infotrans 2009, 117-125.

UIC Code 406: Capacity. 2004. International Union of Railways. 226 p. Available from Internet: <http://banportalen. banverket.se/Banportalen/upload/1753/HandbokUIC406. pdf $>$.

Wahlborg, M. 2004. Draft Final Report Capacity Calculations Sweden. Stockholm: UIC-SJ. 88 p. 